Ethiopian Journal of Environmental Studies \& Management 8(Suppl. 1): 759 - 770, 2015.

ISSN:1998-0507

doi: http://dx.doi.org/10.4314/ejesm.v8i1.3S

Submitted: April 30, 2015

Accepted: September 18, 2015

\title{
THE PLACE OF FIRMS INVESTMENT IN AGGLOMERATION ECONOMIES AMONGST INDUSTRIES IN THE LAGOS REGION, NIGERIA
}

FAGBOHUNKA, A. AND *FATUSIN, A.F.

Geography and Planning Sciences Department, PMB 001, Adekunle Ajasin University, Akungba Akoko, Ondo State, Nigeria

\begin{abstract}
This paper underscores the place of firms' investment in agglomeration economies in the Lagos region, Nigeria. The first stage in the collection of primary data involves the reconnaissance survey of the study area, while the second stage involves the administration of questionnaire to 103 firms in the twelve industrial estates of the region. All the firms identified during the reconnaissance survey were successfully covered. The paper revealed that majority of the firms invested above two hundred million naira in their plants. Agglomeration economies enjoyed include; power supply economies, transport economies, research and development economies and labour economies among others. The canonical correlation analysis carried out to test the influence of firms investment on the degree of agglomeration economies enjoyed amongst firms was significant, the analysis revealed Fvalue 3.2045 and the tabulated F-value 2.70. Result revealed that firms' investments led to the use of improved technology, increased capacity utilization, acquisition of adequate and right personnel (labour), increased output, and realisation of more economies. The contribution of firm's investment to agglomeration economies has positively boosted the local economy. The study recommends that governments have an important role to play in encouraging small, medium and large scale enterprises. This could be achieved by given tax holiday to start-up investors, relaxation of the laws governing the importation of raw materials. A financial assistance in form of loan should be given to interested investors, while the collateral securities should be affordable.
\end{abstract}

Key Words: Firms investment, Agglomeration economies, Lagos Region

\section{Introduction}

Agglomeration economies are the benefits enjoyed by firms locating in the same place. The concentration of the production facilities of a single firm or across multiple firms in a single location generates cost-saving scale effects and often leads to further agglomeration of firms through an industrial location process (Weber, 1929; Venables, 2008). Such cost saving effects of agglomeration is often called agglomeration economies.
Agglomerative activity can take many forms (Simmie, 1997)) and is often considered to result in either "localization "or "urbanization "(external) economies dependent upon the industrial composition of the cluster or complex. Localization economies involve economies amongst similar firms, while economies amongst unlike firms are known as urbanization economies. The latter form of agglomeration has received greater attention in the literature, often providing a 
mechanism for analyses of differential urban growth and optimal city size.

The economies of scale that are enjoyed by the manufacturing establishments in metropolitan areas account for the concentration of these industries in the city. These economies of scale are both internal and external. The internal economies enjoyed by the firms that are concentrated in an area may include managerial economies, which are likely to be those derived from specialization. External economies are also realized through a trade association. Marketing economies, both in the purchase of raw materials and components, and also in the sale of finished products are other advantages derived by firms that agglomerate over space. The concentration of industries with functional linkages in industrial agglomeration brings about financial savings on the part of industries concerned. Such savings are achieved because agglomerated firms can share common services such as water, communication facilities, security, transport facilities and labour. Individual industries are thus saved from the cost of providing these services for themselves. Such financial savings are referred to as external economies of scale. Agglomeration also has the advantage of concentrating labour, managerial skill, capital and customers in specific places, thereby making such places still more attractive to industries.

Coe, (2009), imply that production is more efficient or cost effective when it is spatially concentrated. Firms benefit from the proximity of firms that are in the same industry or are suppliers, (demanders) of their inputs (outputs). Negative spillovers, or insufficient density to facilitate economical production, can conversely be called thin market effects. Once an agglomeration of firms becomes established, progressively more external economies are created forming a cumulative process. The propensity to agglomerate (locationally) increases further either when transactions include small-scale, irregular, unstandardized, or contact-intensive activities that have high unit linkage costs, or when firms seek to reduce demand fluctuations by improving their customer base through locational clustering (Leung, 1993). Flexible regime of accumulation encompasses new forms of production characterized by a welldeveloped ability to shift promptly from one process and/or product arrangement to another it mechanism for rapidly adjusting to changes in the market without harmful effects on the level of efficiency; these have encouraged agglomeration and competitiveness amongst firms. On the other hand, the location dispersal of production occurs when the transaction involves bulky, stable, standardized, or easily manageable activities that have low unit linkage costs. These activities "contain primarily routine deskilled production process and are dispersed to peripheral areas where labour or land costs are low" (Scott 1993).

The existence of externalities and increasing returns to scale in production is the most important explanatory factor for the geographic concentration of firms. Even if individual firms face constant internal returns to scale, agglomeration may generate externalities that create productivity advancements for individual firms in a given locations and therefore lead to increasing returns to scale at an aggregate level.

Based on the two variables of the number of employees and the sum of capital investment, the Nigerian government recognizes large and small scale manufacturing plants. A small scale establishment is the one that employed 50 employees or less and has $\$ 750,000.00$ or less capital investment (federal 
government of Nigeria, 1985). While large scale manufacturing plants are those that employed more than 50 employees and their capital based (share capital investment) is far greater than $\$ 750$, 000.00 .

\section{Study Area}

The Lagos region is situated along the south west of Nigeria, approximately between latitudes $6^{\circ} 27^{\prime}$ and $6^{\circ} 37^{\prime}$ north of the equator and longitudes $3^{\circ} 15^{\prime}$ and $3^{\circ} 47^{\prime}$ east of Greenwich meridian (Figure 1), with a land area of about $1,088 \mathrm{~km}^{2}$, covers about 32 percent of the land area of Lagos State. About 20 percent of this area is made up of Lagoons and mangrove swamps.

Lagos region is the leading, industrial, commercial, financial and maritime nervecentre of the country. Over 60 percent of all commercial transactions in Nigeria are carried out or finalized in the Lagos region. About 70 percent of the total value of industrial investments in Nigeria is in the Lagos region. Over 65 percent of the country's industrial employment is concentrated in this region, leaving the remaining 35 percent in other parts of the country. It is, in part, the recognition of the marked concentration of industries in the Lagos region that informed its choice as the study area for this work.

Perhaps it is this strategic position of the Lagos region within the country, which explains why industrial concerns and trading companies, such as United African Company (UAC), Union Trading Company (UTC), Patterson and Zochonis (PZ), have their head offices, located in this region. In addition, major financial centres such as the Nigerian Stock Exchange and the head office of major banks, insurance companies and other financial institutions are located in this region. The Lagos region has two seaports, Tincan and Apapa. The two ports handle about 60 percent of Nigeria's total export excluding crude oil and about 70 percent of imports. Major terminals for both road and rail routes are located in the Lagos region. The strategic location of the Lagos region is further strengthened by the presence of the most important airport.

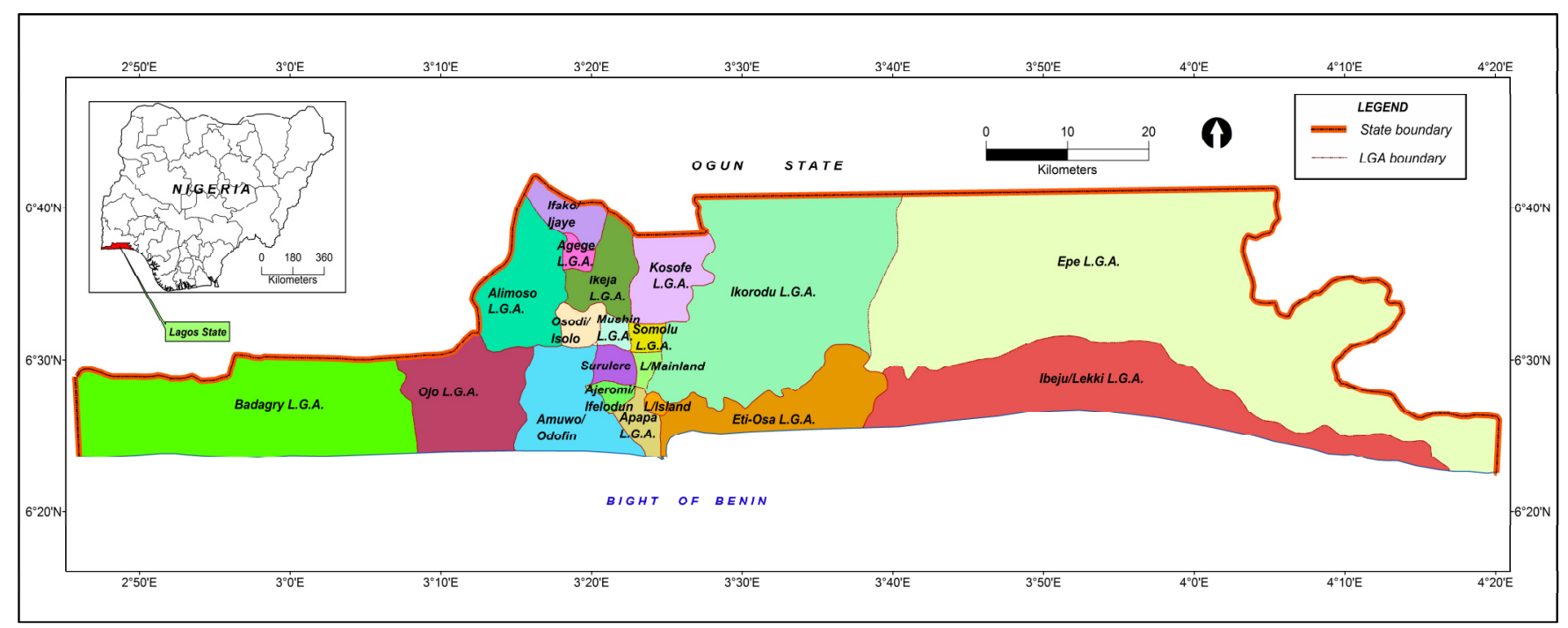

Figure 1: Lagos Region

\section{Methods}

Questionnaire was designed to elicit information on the place of firm's investment in agglomeration economies amongst firms. All the firms identified during the reconnaissance survey were 
covered in the questionnaire administration. The questionnaire was administered such that firms in each of the industrial estates/areas and the outlying firms were visited one after the other. In each case, the questionnaires were left with the industrialist/designated officer to complete. One hundred and three questionnaire were administered in twelve industrial estates; one questionnaire in each of the firm. This connotes that all the firms in the industrial estates were successfully covered in the questionnaire administration, which was administered. All the questionnaires were retrieved.

\section{Result and Discussion Firm's Investment}

Figure 2 shows the estimated firms investment. Out of $103(100 \%)$ firms, 9 $(8.7 \%)$ firms invested less than $\$ 1 \mathrm{~m}, 12$ (11.7\%) firms invested between $¥ 1 \mathrm{~m}-50 \mathrm{~m}$ naira, $4(3.9 \%)$ firms invested between $\$ 51 \mathrm{~m} \$ 100$ while, 8 (7.8\%) firms invested between $\$ 101 \mathrm{~m}$ - $\$ 150 \mathrm{~m}$, also, 11 (11\%) firms invested between $151 \mathrm{~m}$ - $\$ 200 \mathrm{~m}$ and $59(57 \%)$ firms invested above $\$ 200 \mathrm{~m}$. It is apparent that many of the firms invested above $200 \mathrm{~m}$; this also points to the fact that most of the firms are large scale industries, federal government 1990 opined that large scale industries are those firms having above 750,000.00 investments.
Figure 3 shows the estimated firm's investment in each of the estates. Out of $9(8.7 \%)$ firms that invested $<\mathrm{N} 1 \mathrm{~m}$, $2(1.9 \%)$ are in Ikorodu while $1(0.97 \%)$ firms each are in Agbara, Ikeja, Ilupeju, Oshodi/Isolo, Oregun and Surulere/Mushin. Out of the 12(11.7\%) firms that invested between $\mathrm{N} 1 \mathrm{~m}$ and N50m, 3(2.9\%) are in Apapa, 1(0.97\%) each are in Matori, Ikeja, Ilupeju, Oregun and Surulere/Mushin. Another 4(3.9\%) firms invested between N51m and N100m, out of which $3(2.9 \%)$ firms are in Ikeja, only $1(0.97 \%)$ in Apapa.

Out of the $8(7.8 \%)$ firms that invested between $\mathrm{N} 151$ and $\mathrm{N} 200 \mathrm{~m}, 3(2.9 \%)$ are in Apapa, while 2(1.9\%) firms each are in Agbara, Ikeja and Ilupeju. Whereas only $1(0.94 \%)$ is in Oshodi/Isolo. Furthermore, out of $11(10.7 \%)$ firms that invested between $\mathrm{N} 101 \mathrm{~m}$ and $\mathrm{N} 150 \mathrm{~m}, 3(2.9 \%)$ are in Apapa, while $1(0.97 \%)$ is in Matori, Agbara, Ikeja, Ilupeju and Oshodi/Isolo. Out of the $59(57 \%)$ firms that invested above N200m, 16(15.5\%) are in Ikeja, while $9(8.7 \%)$ are in Ilupeju. Also, $7(6.8 \%)$ were in Oregun, whereas 6(5.8\%) firms each were in Iganmu and Oshodi/Isolo. Another, 5(4.9\%) firms are in Surulere/Mushin, while there are $2(1.9 \%)$ firms each in Apapa and Ogba. Only 1(0.97\%) firms in Ikorodu. 


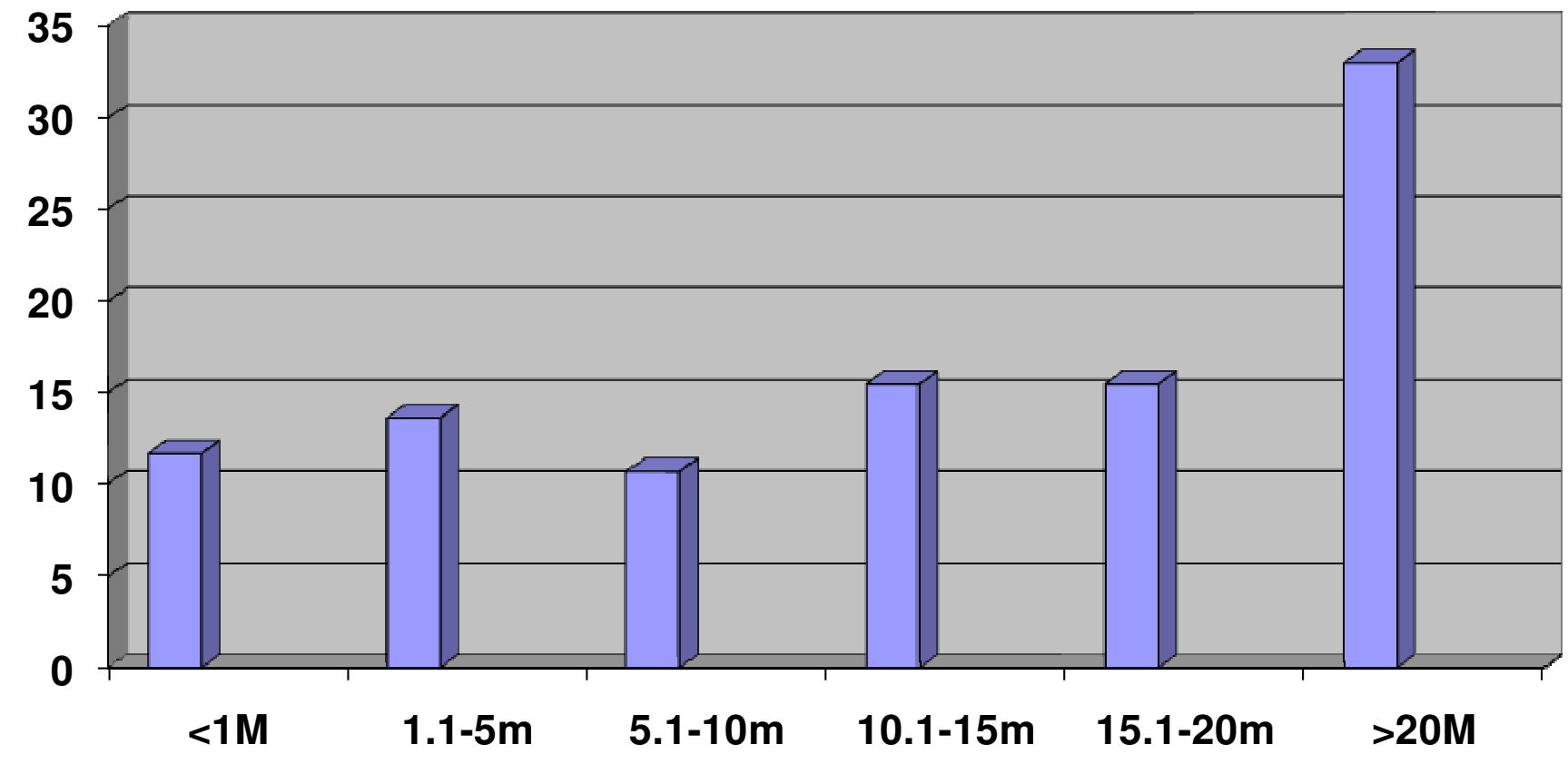

Figure 2: Firms Investment 


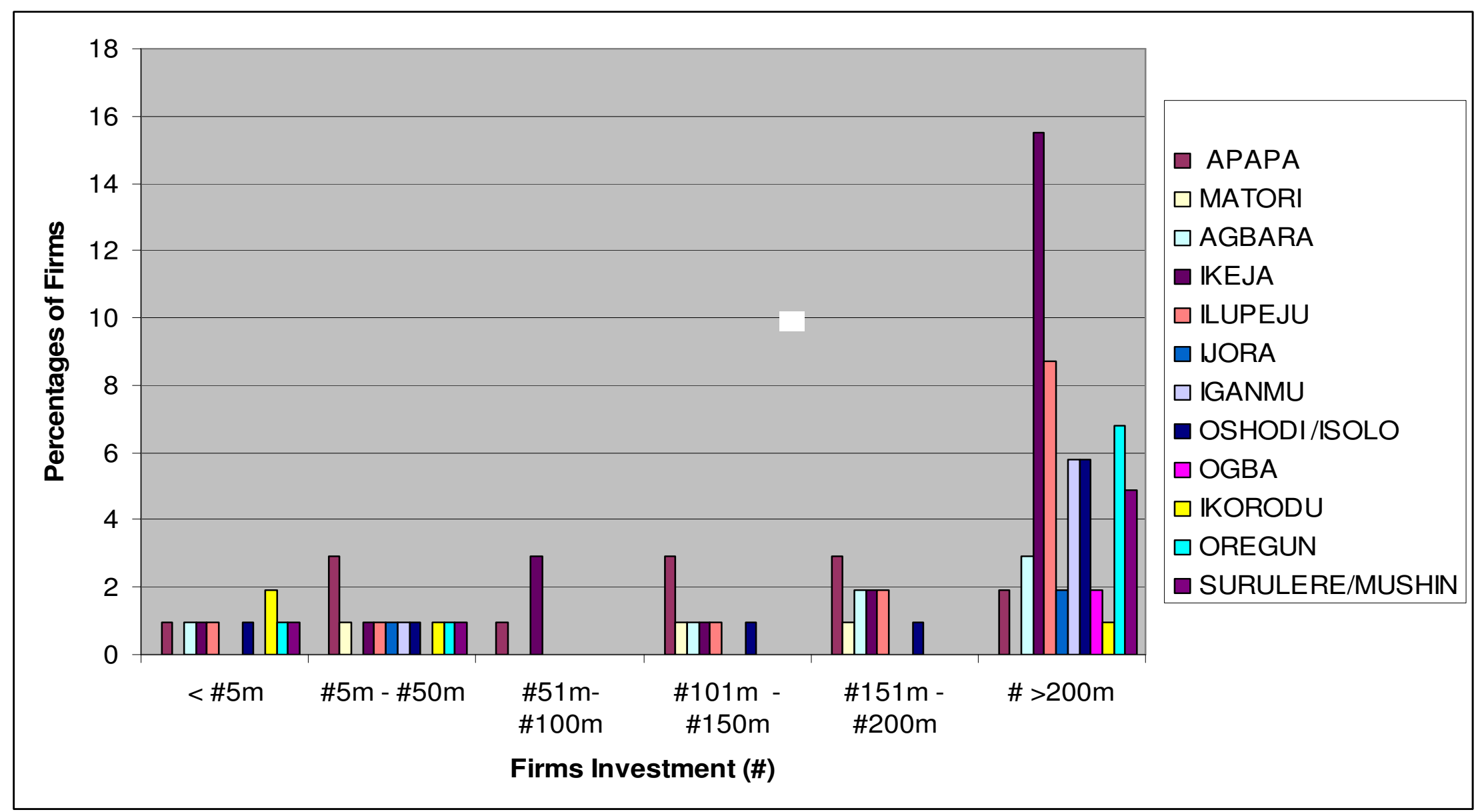

Figure 3: Estimated Firms Investment on the Basis of the Estates 


\section{Gross Financial Annual Output}

Table 1 shows the gross financial annual output of firms. Out of $103(100 \%)$ firms, 5 (4.9\%) firms have less than $\$ 10 \mathrm{~m}$, $22(21.4 \%)$ firms have between $\$ 10 \mathrm{~m}-$ $\$ 100 \mathrm{~m}, 4$ (3.9\%) firms have gross financial annual output between $\$ 101 \mathrm{~m}-\$ 190 \mathrm{~m}$, while, 3 (2.9\%) firms have between $\$ 191 \mathrm{~m}$ - $281 \mathrm{~m}$, only $2(1.9 \%)$ firms have between $\$ 282 \mathrm{~m}-\$ 372 \mathrm{~m}, 67(65 \%)$ firms have above $\$ 372 \mathrm{~m}$ gross financial annual output. This connotes that majority of the firms have gross financial annual output above $\$ 372 \mathrm{~m}$.

Table 1 Gross Financial Annual Output of Firms

\begin{tabular}{lll}
\hline Gross financial annual output of Firms & No of Firms & Percentage \\
\hline Less than $¥ 10 \mathrm{~m}$ & 5 & 4.9 \\
$10 \mathrm{~m}-\$ 100 \mathrm{~m}$ & 22 & 21.4 \\
$101 \mathrm{~m}-\$ 190 \mathrm{~m}$ & 4 & 3.9 \\
$191 \mathrm{~m}-\$ 281$ & 3 & 2.9 \\
$282 \mathrm{~m}-\$ 372 \mathrm{~m}$ & 2 & 1.9 \\
Greater than $372 \mathrm{~m}$ & 67 & 65 \\
TOTAL & $\mathbf{1 0 3}$ & $\mathbf{1 0 0}$ \\
\hline
\end{tabular}

Table 2 shows the gross financial annual output in each of the estates. Out of the $5(4.9 \%)$ firms having $<\mathrm{N} 10 \mathrm{~m}$ gross financial annual output, 2(1.9\%) firms are in Oregun and 1(0.97) firm's each are in Apapa, Ikeja and Ilupeju. Another, $22(21.4 \%)$ firms have between $\mathrm{N} 10 \mathrm{~m}$ and $\mathrm{N} 100 \mathrm{~m}$ gross financial annual output, out of which 5(4.9\%) each are in Apapa and Ikeja. While there are $2(1.9 \%)$ firms each in Ilupeju, Oshodi/Isolo, Ogba and Oregun. Also, out of $4(3.9 \%)$ firms having between $\mathrm{N} 101 \mathrm{~m}$ and $\mathrm{N} 190 \mathrm{~m}, 2(1.9 \%)$ are in Agbara, only $1(0.97 \%)$ each in Apapa and Matori.
Furthermore, out of the $3(2.9 \%)$ firms that have between $\mathrm{N} 191 \mathrm{~m}$ and $\mathrm{N} 281 \mathrm{~m}$ gross financial annual output, 2(1.9\%) firms are in Apapa, only 1(0.97\%) in Ikeja. Moreover, out of the $2(1.94 \%)$ firms that have between $\mathrm{N} 282 \mathrm{~m}$ and $\mathrm{N} 372 \mathrm{~m}$, only $1(0.97 \%)$ each in Apapa, and Ikeja. Out of the 66(64.07\%) firms that have above $\mathrm{N} 372 \mathrm{~m}$ gross financial annual output, $17(16.5 \%)$ are in Ikeja, 8(7.8\%) in Ogba, whereas there are $5(4.9 \%)$ firms each in Agbara, and Oshodi/Isolo. Another 6(5.8\%) in Surulere/Mushin, while there are $3(2.9 \%)$ in Apapa. Also, there are 2(1.9\%) firms Iganmu and $1(0.79 \%)$ each in Matori and Ikorodu.

Table 2 Gross Financial Annual Output on the Basis of the Estates

\begin{tabular}{|c|c|c|c|c|c|c|c|c|c|c|c|c|}
\hline & \multicolumn{2}{|c|}{$<\# 10 \mathrm{~m}$} & \multicolumn{2}{|c|}{$\# 10 \mathrm{~m}-100 \mathrm{~m}$} & \multicolumn{2}{|c|}{$\# 101 \mathrm{~m}-\# 190 \mathrm{~m}$} & \multicolumn{2}{|c|}{$\# 191 \mathrm{~m}-\# 281 \mathrm{~m}$} & \multicolumn{2}{|c|}{$\# 282 \mathrm{~m}-\# 372 \mathrm{~m}$} & \multicolumn{2}{|c|}{$>\# 372 \mathrm{~m}$} \\
\hline & No & $\%$ & No & $\%$ & No & $\%$ & No & $\%$ & No & $\%$ & No & $\%$ \\
\hline Apapa & 1 & 0.97 & 5 & 4.9 & 1 & 0.97 & 2 & 1.9 & 1 & 0.97 & 3 & 2.9 \\
\hline Matori & & & 1 & 0.97 & 1 & 0.97 & & & & & 1 & 0.97 \\
\hline Agbara & & & & & 2 & 1.9 & & & & & 5 & 4.9 \\
\hline Ikeja & 1 & 0.97 & 5 & 4.9 & & & 1 & 0.97 & & & 17 & 16.5 \\
\hline Ilupeju & 1 & 0.97 & 2 & 1.9 & & & & & & & 11 & 10.7 \\
\hline Iganmu & & & 1 & 0.97 & & & & & & & 2 & 1.9 \\
\hline Oshodi/Isolo & & & 2 & 1.9 & & & & & & & 5 & 4.9 \\
\hline Ogba & & & 2 & 1.9 & & & & & 1 & 0.97 & 8 & 7.8 \\
\hline Ikorodu & 2 & 1.9 & 1 & 0.97 & & & & & & & 1 & 0.97 \\
\hline Oregun & & & 2 & 1.9 & & & & & & & 7 & 6.8 \\
\hline Surulere /Mushin & & & 1 & 0.97 & & & & & & & 6 & 5.8 \\
\hline TOTAL & 5 & 4.9 & 22 & 21.4 & 4 & 3.9 & 3 & 2.9 & 2 & 1.94 & 66 & 64.07 \\
\hline
\end{tabular}


Table 3: Agglomeration economies Amongst Firms

\begin{tabular}{|c|c|c|c|c|c|c|c|c|c|c|c|c|c|c|c|c|c|c|c|c|c|c|}
\hline \multirow[t]{2}{*}{$\begin{array}{l}\% \\
\text { Savings }\end{array}$} & \multicolumn{2}{|c|}{$\begin{array}{l}\text { Joints } \\
\text { Transportati } \\
\text { on }\end{array}$} & \multicolumn{2}{|c|}{$\begin{array}{l}\text { Joint Power } \\
\text { Supply }\end{array}$} & \multicolumn{2}{|c|}{$\begin{array}{l}\text { Joint Raw } \\
\text { Material } \\
\text { Purchase/Su } \\
\text { pply }\end{array}$} & \multicolumn{2}{|c|}{$\begin{array}{l}\text { Collaboratio } \\
n \text { in } R \text { \& D }\end{array}$} & \multicolumn{2}{|c|}{ Joint labour } & \multicolumn{2}{|c|}{$\begin{array}{l}\text { Joint Water } \\
\text { Supply }\end{array}$} & \multicolumn{2}{|c|}{$\begin{array}{l}\text { Joint waste } \\
\text { treatment }\end{array}$} & \multicolumn{2}{|c|}{ Joint Security } & \multicolumn{2}{|c|}{$\begin{array}{l}\text { Joint } \\
\text { telecomm }\end{array}$} & \multicolumn{2}{|c|}{$\begin{array}{l}\text { Joint port } \\
\text { \& shipping }\end{array}$} & \multicolumn{2}{|c|}{$\begin{array}{l}\text { Access to } \\
\text { financial } \\
\text { institution }\end{array}$} \\
\hline & No. & $\%$ & No. & $\%$ & No. & $\%$ & No. & $\%$ & No. & $\%$ & No. & $\%$ & No. & $\%$ & No. & $\%$ & No. & $\%$ & No. & $\%$ & No. & $\%$ \\
\hline$<10$ & 29 & 28.2 & 38 & 36.9 & 24 & 23.3 & 42 & 40.7 & 43 & 41.7 & 60 & 58 & 53 & 51.5 & 55 & 53 & 79 & 76.7 & 51 & 49.5 & 20 & 19.4 \\
\hline $11-20$ & 10 & 9.71 & 18 & 17.5 & 26 & 25.2 & 12 & 11.7 & 18 & 17.5 & 19 & 18 & 06 & 5.8 & 16 & 15.5 & 15 & 14.6 & 7 & 6.8 & 17 & 16.5 \\
\hline $21-30$ & 20 & 19 & 9 & 8.7 & 9 & 8.7 & 3 & 2.9 & 17 & 16.5 & 9 & 9 & 12 & 11.7 & 12 & 11.7 & 8 & 7.8 & 13 & 12.6 & 12 & 11.7 \\
\hline $31-40$ & 10 & 9.71 & 1 & 0.97 & 6 & 5.8 & 10 & 9.71 & 4 & 3.9 & 10 & 10 & 11 & 10.7 & 7 & 6.8 & 1 & 0.97 & 10 & 9.71 & 07 & 6.8 \\
\hline $41-50$ & 14 & 13.6 & 19 & 18.4 & 6 & 11.7 & 17 & 16.5 & 15 & 14.6 & 3 & 3 & 8 & 7.8 & 5 & 4.9 & - & - & 5 & 4.9 & 25 & 24.3 \\
\hline $51-60$ & 10 & 9.71 & 9 & 8.7 & 10 & 16.5 & 9 & 8.7 & 06 & 5.8 & 2 & 1.94 & 10 & 9.71 & 5 & 4.9 & - & - & 12 & 11.7 & 9 & 8.7 \\
\hline $61-70$ & 05 & 4.9 & 7 & 6.8 & 4 & 7.8 & 8 & 7.8 & - & - & - & - & 1 & 0.97 & 2 & 1.94 & - & - & 5 & 4.9 & 5 & 4.9 \\
\hline $71-80$ & 1 & 0.97 & 2 & 1.94 & 1 & 0.97 & 2 & 1.94 & - & - & - & - & 1 & 0.97 & 1 & 0.9 & - & - & - & - & 3 & 2.9 \\
\hline $81-90$ & 2 & 1.94 & - & - & - & - & - & - & - & - & - & - & 1 & 0.97 & - & - & - & - & - & - & 5 & 4.9 \\
\hline $91-100$ & - & - & - & - & - & - & - & - & - & - & - & - & - & - & - & - & - & - & - & - & - & - \\
\hline Total & 103 & 100 & 103 & 100 & 103 & 100 & 103 & 100 & 103 & 100 & 103 & 100 & 103 & 100 & & & 103 & 100 & 103 & 100 & 103 & 100 \\
\hline
\end{tabular}


The benefits of agglomeration are revealed in table 3 , these benefits ranges from joint transportation to access to financial institution. Due to joint transportation, only $1(0.97 \%)$ firms saved between $81-90 \%$, whereas as a result of joint power supply; $(7.8 \%)$ firms realized between 61 and $70 \%$. The percentage savings in collaboration in research and development indicated that $17(16.5 \%)$ firms saved between 41 and $50 \%$, whereas $15(14.6 \%)$ firms realised between 41 and $50 \%$ as a result of joint labour. Also, $5(4.9 \%)$ firms saved between $61-80 \%$ due to joint ports and shipping, while three (2.9\%) firms realized between 71 and $80 \%$ as a result of access to financial institution.

Table 4: Firms Investment and its Influence in Agglomeration Economies

\begin{tabular}{lll}
\hline $\begin{array}{l}\text { Contribution of Firms Investment to } \\
\text { Agglomeration Economies }\end{array}$ & Frequency & Percentage \\
\hline $\begin{array}{l}\text { Adequate Infrastructure } \\
\text { Recruitment of adequate and Right }\end{array}$ & 50 & 15 \\
$\begin{array}{l}\text { Personnel } \\
\text { Improved Collaboration in research }\end{array}$ & 34 & 13 \\
and development & 34 & 10 \\
Adequate Sales promotion & 47 & 10 \\
The use of Sophisticated Equipments & 29 & 14 \\
Industrial Expansion & 27 & 9 \\
Increased Output & 40 & 8 \\
Improved Productivity & 24 & 12 \\
Production Sustenance & 6 & 7.2 \\
Realisation of more Economies & 333 & 1.8 \\
Total & & 100 \\
\hline
\end{tabular}

The total is greater than 103 because of multiple responses.

Table 4 depicts the contribution of firms investment to agglomeration economies enjoyed amongst firms. Fifty (15\%) firms opined adequate infrastructure, 47(14\%) agreed that firms investment has contributed to the use of sophisticated equipments to boost production. Also, 24(7.2\%) believed that firms investment has sustained production, whereas $6(1.8 \%)$ opined realisation of more economies. This has lends credence that the place of firms investment is germane to industrial survival, especially in the areas of increased agglomeration economies which is vital to economic rejuvenation.

The degree of agglomeration economies enjoyed by firms is not determined by firms investment was tested using the canonical correlation statistical technique.
Table 5 shows the result of Canonical Correlation Analysis of agglomeration economies and structural characteristics of firms. It reveals that agglomeration economies have a stronger variation coefficient, with $r$ value of $0.8027, \mathrm{r}^{2}$ value of 0.62 and $62 \%$ variance, while the firm's investment has $r$ value of $0.7033, r^{2}$ value of 0.51 and $51 \%$ of variance.

The Roy's Largest Root Test depicted in table 6 was employed to test for the significance of the canonical correlations at 0.05 significant levels; result of the test shows the calculated F-value 3.2045 and the tabulated F-value 2.70. The calculated F-value is greater than the tabulated value. This suggests that the degree of agglomeration economies enjoyed by firms is significantly explained by the firm's investment. 
Table 5: Summary of result of Canonical Correlation Analysis

\begin{tabular}{lcccc}
\hline Variables & $\begin{array}{c}\text { Canonical Correlation } \\
(\mathrm{r})\end{array}$ & $\mathrm{r}^{2}$ & $\%$ of variance & Decision \\
\hline Set I & 0.8027 & 0.62 & $62 \%$ & Accept $\mathrm{H}_{1}$ \\
$\mathrm{Y}_{1-11}$ & & & & \\
Set II & 0.7033 & 0.51 & $51 \%$ & \\
$\mathrm{X}_{111}-\mathrm{X}_{555}$ & &
\end{tabular}

Table 6: Roy's Largest Root Test of Significant

\begin{tabular}{lcccccc}
\hline $\mathrm{R}$ & $\mathrm{df}_{\mathrm{r}}$ & $\mathrm{df}_{\mathrm{c}}$ & Level of Significant & Calc. F & Tab. F. & Decision \\
\hline 0.8027 & 11 & 9 & $5 \%$ & 3.2045 & 2.70 & $\mathrm{H}_{1}$ is accepted \\
0.7033 & & & & & & \\
\hline
\end{tabular}

Table 7 The Most Significant Infrastructure as the Dominant contributor to Agglomeration Economies

\begin{tabular}{lll}
\hline Most Significant Infrastructure & Frequency & Percentage \\
\hline Telecommunication & 2 & 1.6 \\
Water Supply & 42 & 33.1 \\
Good Road Net work & 12 & 9.4 \\
Sewers & 10 & 7.9 \\
Electricity & 49 & 38.6 \\
Hospitals & 4 & 3.1 \\
Parks & 8 & 6.3 \\
Total & 127 & 100 \\
\hline
\end{tabular}

The total is greater than 103 because of multiple responses.

Table 7 reveals the most significant infrastructure, which is the dominant contributor to agglomeration economies enjoyed as a result of firms investment. Only 2(1.6\%) firms opined telecommunication, while 42(33.1\%) agreed water supply. Another 49(38.6\%) believed that electricity has significantly contributed to the agglomeration economies, whereas $12(9.4 \%)$ agreed that good roads contributed the most. Also, $10(7.9 \%)$ firms opined sewers, while $8(6.3 \%)$ believed that parks has the most contribution.

It is apparent that telecommunication is not a significant contributing factor to agglomeration economies, while electricity is very germane in contributing to agglomeration economies. This lends credence to the facts that proximity of firms could lead to joint power supply, which is a concerted efforts towards production sustenance.

Table 8: The Firms Notion about their Investment and Agglomeration Economies Contribution to the Local Economy

\begin{tabular}{lll}
\hline Contributions & Frequency & Percentage \\
\hline Very Significant & 58 & 56 \\
Fairly Significant & 33 & 32 \\
Significant & 9 & 9 \\
Averagely Significant & 3 & 3 \\
Insignificant & - & - \\
Total & 333 & 100 \\
\hline
\end{tabular}

Table 8 shows the contribution of firm's investment and agglomeration economies to the local economy. Out of $103(100 \%)$ firms, 58(56.3\%) attested a very significant contribution, while $33(32 \%)$ attested fairly significant. Furthermore, 9 (9\%) opined significant 
contribution, whereas 3(\%) believed an averagely contribution. It is obvious from the analysis that firms' investment and the agglomeration economies are catalysts which serve as an economic booster.

\section{Summary and Conclusion}

The paper has examined the place of firm's investment in agglomeration economies amongst firms in the Lagos region, Nigeria. The research has found out that many of the firms invested above $\$ 200 \mathrm{~m}$; this also points to the fact that most of the firms are large scale industries. Furthermore, majority of the firms have gross financial annual output above $\$ 372 \mathrm{~m}$. Agglomeration economies varied significantly amongst these firms, the agglomeration economies enjoyed includes; transportation economies, labour economies, ports and shipping, research and development economies, power economies, water supply economies, waste treatment economies, security economies, raw material /purchasing economies, telecommunication as well as access to financial institution. The contributions of firm's investment to agglomeration economies are diverse, including; adequate infrastructural provision, recruitment of adequate and right personnel, industrial expansion, and increased output, adequate sales promotion, the use of quality and sophisticated equipments, improved productivity and production sustenance, improved collaboration in research and development and realisation of more economies. It must be noted that adequate infrastructural facility provisions was the most significant of all the contributions of firms investment to agglomeration economies; this has lends credence to the fact that firms investment is germane to industrial survival, especially in the areas of increased agglomeration economies. To further ascertain the place of firm's investment in agglomeration economies amongst firms, a test was carried out and the result of the test i.e. in relation to the influence of firms' investment on degree of agglomeration economies enjoyed by firms, using the canonical correlation statistical technique shows the calculated F-value 3.2045 and the tabulated F-value 2.70. This revealed that the degree of agglomeration economies enjoyed by firms is significantly explained or determined by the firm's investment, this signify a positive relationship.

Agglomeration of firms therefore could be likening to a catalyst and socio economic booster in regional revamping and development. The economies generated have a multiplier effect and positively aiding other sector of the economy. Agglomeration of firms needs to be encouraged, because its encouragement will culminate to realisation of more economies. In the light of this; the paper recommends that: the industrial enterprise should be encouraged through active government participation and the provision of adequate infrastructural facilities in the industrial estates. Also credit facilities should be accorded to interested entrepreneur to facilitate industrial expansion. Government should implement tax holiday policy in order to encourage younger investors.

\section{References}

Coe, D., Helpman, E. and Hoffmaister, (2009). International R \& D Spillovers and Institutions, European Economic Review, 53(7): Pp. 723741.

Leung, C. K. (1993). "Personal contacts, sub contracting linkages and development in the Hong Kong Zhijiang Delta Region". Annals of the Association of American Geographers, 83(2): 273-302. 
Scott, A. (2006). Environmental Impacts of Small Scale Industries in Third World Countries. Global Environmental Changes Programme, University of Sussex, w.sussex. ac.uk.

Scott, A.J. (1993b). Technopolis: High Technology Industry and Regional Development in Southern California. Berkeley, University of California Press.

Scott, A.J. and Bergman D. (1995). "The Industrial Resurgence of Southern California? Advanced Ground Transportation Equipment Manufacturing and Local Economic Development". Environment and Planning C: Government and Policy, 13, pp. $97-124$.

Scott, A.J. (1988a). New Industrial Spaces: Flexible Production, Organization and Regional Development in North
America and Western Europe. London: Pion.

Simmie, J. (Ed.) (1997). Innovation, Networks and Learning Regions? London: Jessica Kingsley.

Storper, M. (2000). Regional Technology policies in Europe : A reflection on TSER Projects, 1998- 2000 and where to go from there. Paper prepared for the workshop on regional level of implementation of innovation and education and Training Policies. European Commission, Research Directorate General. Brussels, November 23 14,2000

Venables, A. (2008). New Economic Geography: The New Palgrave Dictionary of Economics, $2^{\text {nd }}$ Edition Abstract.

Weber, A. (1929). Theory of the Location of Industries. Chicago: University of Chicago Press. 